\title{
Rehabilitation of asbestos mining waste: a Rehabilitation Prioritisation Index (RPI) for South Africa
}

\author{
L. van Rensburg $\cdot$ S. Claassens $\cdot$ J. J. Bezuidenhout $\cdot$ \\ P. J. Jansen van Rensburg
}

Received: 10 October 2007 / Accepted: 11 February 2008/Published online: 5 March 2008

(C) The Author(s) 2008

\begin{abstract}
The much publicised problem with major asbestos pollution and related health issues in South Africa, has called for action to be taken to negate the situation. The aim of this project was to establish a prioritisation index that would provide a scientifically based sequence in which polluted asbestos mines in Southern Africa ought to be rehabilitated. It was reasoned that a computerised database capable of calculating such a Rehabilitation Prioritisation Index (RPI) would be a fruitful departure from the previously used subjective selection prone to human bias. The database was developed in Microsoft Access and both quantitative and qualitative data were used for the calculation of the RPI value. The logical database structure consists of a number of mines, each consisting of a number of dumps, for which a number of samples have been analysed to determine asbestos fibre contents. For this system to be accurate as well as relevant, the data in the database should be revalidated and updated on a regular basis.
\end{abstract}

Keywords Amphibole - Asbestos · Chrysotile · Mining $\cdot$ Rehabilitation $\cdot$ Serpentine $\cdot$ Prioritisation

\section{Abbreviation}

RPI Rehabilitation Prioritisation Index

L. van Rensburg ( $₫)$. S. Claassens · J. J. Bezuidenhout .

P. J. Jansen van Rensburg

School of Environmental Sciences and Development,

North-West University, Potchefstroom Campus,

PB X6001, Potchefstroom 2520, South Africa

e-mail: leon.vanrensburg@nwu.ac.za

\section{Introduction}

Asbestos occurs naturally in almost $60-70 \%$ of the earth's crust and is found in two varieties: serpentine and amphibole asbestos. The most common asbestos types are chrysotile (white asbestos), which is a fibrous serpentine asbestos; and amosite (brown asbestos) and crocidolite (blue asbestos), which are amphiboles. Other forms of amphibole asbestos include actinolite, anthophyllite and tremolite (NICNAS 1999).

Asbestos has a number of applications in construction and manufacturing processes due to several industrially desirable characteristics, including: high tensile strength, fire and heat resistance, durability and versatility (Harris and Kahwa 2003). However, due to the harmful health effects of asbestos dust mining (McDonald and McDonald 1997; Tossavainen et al. 2001), the use of asbestos materials in developed nations has been decreasing. During the twentieth century, evidence suggested that asbestos fibres could lead to serious health disorders, such as asbestosis, lung cancer and mesothelioma. Subsequently, asbestos became the focus of extensive scientific and medical research. Research indicated that all asbestos fibres are not alike and that fibre length and type, dose and exposure play a significant role in the health risk associated with occupational and environmental exposure to asbestos fibres (Harris and Kahwa 2003; Natural Resources Canada 2000). Scientific consensus exists on the fact that fibres in the amphibole group are more harmful (100-500 times) to health than chrysotile, particularly for mesothelioma (Anon. 2004).

Asbestos mining waste poses a significant health risk to those living in surrounding areas and has received much attention in recent years (Harris and Kahwa 2003). Despite the fact that all the asbestos mines and mills in South 
Africa are now effectively closed, this industry has left a legacy of pollution that continues to poison former mining areas as well as surrounding areas, including school yards, roads, gardens and homes of residents (Anon. 2001). The much publicised problem with major asbestos pollution and related health issues in South Africa, has called for action to be taken to negate this situation. The development of a prioritisation index for the rehabilitation of South Africa's asbestos mining waste sites is a step in that direction.

\section{Synthetic methodology and data}

\section{Synopsis}

The database was developed in Microsoft Access and both qualitative and quantitative data were considered for calculation of the rehabilitation prioritisation index (RPI) value. The logical database structure consists of a number of mines (in the respective provinces), each consisting of a number of dumps, for which a number of samples have been analysed to determine asbestos fibre contents. The database structure is outlined by the diagram in Fig. 1. For demonstration purposes two mines from within the database were selected. First, Whitebank mine, Northern Cape Province, South Africa $\left(27^{\circ} 25,75^{\prime} \mathrm{S}\right.$; $\left.23^{\circ} 17,75^{\prime} \mathrm{E}\right)$ and second Senekal mine, Mpumalanga Province, South Africa $\left(25^{\circ} 33,5^{\prime} \mathrm{S} ; 31^{\circ} 28^{\prime} \mathrm{E}\right)$. Senekal is smaller in size than Whitebank, but due to differences in the asbestos hazard and related variables, both have quite high RPI values. Whitebank has a RPI value of $69.33 \%$ while Senekal $71.33 \%$. This serves to indicate that size of the site alone will not determine the overall associated risk.

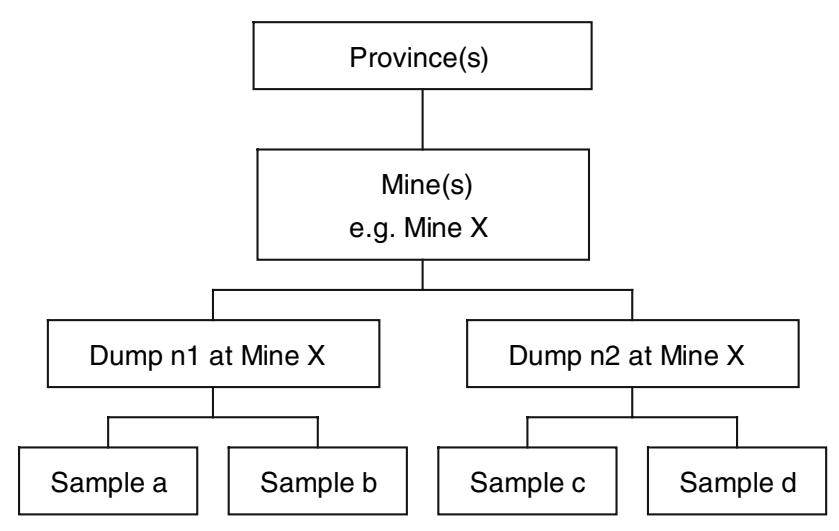

Fig. 1 A diagrammatical representation of the rehabilitation prioritisation index (RPI) database structure
Enumeration of asbestos risk parameters

To collect all relevant information pertaining to a specific mine's pollution source technical personnel conducted site visits during which both qualitative data and samples for quantitative analysis were gathered. Qualitative data included variables such as demographic, geographic, safety and aesthetical considerations that were very difficult to quantify exactly and will always be subjective depending on the experience of the individual who collected the information. A set of definitions describing what was meant by each qualitative data parameter, how this information was obtained and validated, as well as the conversion factors used to incorporate these values into the database was established and are available for use with the database. A summary of these definitions is provided in Table 1. During each site visit a 10-kg sample was collected from every potential mine pollution source and quantitatively analysed in the mini-asbestos processing plant to determine the total percentage of free asbestos fibre in the sample. The percentage of short fibres within the extracted free asbestos fibre was determined by means of a Canadian shake box.

Table 1 contains the definitions of parameters used and assumptions made during the calculation of the RPI value. In addition to the parameters indicated in the table the following were also considered:

Safety This information focused on the presence and number of dangerous highwalls and/or adits, which could serve as a potential source of danger to both humans and animals. The exact numbers of highwalls and/or adits were noted and normalised for incorporation in the calculation of the RPI value.

Aesthetics This information focused on whether past mining activities and indications thereof represent a negative aesthetical impact on the natural environment.

\section{Calculation of the RPI value}

Calculation of the RPI value entailed using a formula in which both the quantitative and qualitative data were taken into consideration, but not in a simple additive manner. For example, because of the non-subjectivity and direct relevance to human health the fibre hazard was considered to contribute $50 \%$ to the calculated RPI. Three important factors contribute to the fibre hazard: (1) the total percentage free fibre as determined by the mini-processing plant, (2) the estimated scale of the exposed surface area of the mine pollution source and (3) the percentage short fibre present in the total free fibre content. When the total percentage free fibre in a sample was equal to or exceeded $1.8 \%$ it could potentially contribute from $8-40 \%$ to the RPI 
Table 1 Parameters of assumptions used during the calculation of the Rehabilitation Prioritisation Index (RPI) value

\begin{tabular}{|c|c|c|}
\hline Fibre hazard & Potential for air pollution & Erosion potential and general pollution \\
\hline $\begin{array}{l}\text { Total percentage of free fibre: a value higher } \\
\text { than } 1.8 \% \text { indicates a need for } \\
\text { rehabilitation }\end{array}$ & $\begin{array}{l}\text { Distance of nearest settlement from pollution } \\
\text { source: this value serves to indicate the } \\
\text { potential for fibre release that can be } \\
\text { caused by normal daily activities }\end{array}$ & Annual rainfall \\
\hline $\begin{array}{l}\text { A sample: typically weighs } 10 \mathrm{~kg} \text { and } \\
\text { collected from the top or bottom } 50 \% \text { of } \\
\text { any dump but could also have been } \\
\text { collected where secondary asbestos } \\
\text { pollution occurred }\end{array}$ & $\begin{array}{l}\text { Number of inhabitants occupying the } \\
\text { settlement adjacent to the pollution source }\end{array}$ & $\begin{array}{l}\text { Located in waterway: only a yes or no } \\
\text { answer }\end{array}$ \\
\hline $\begin{array}{l}\text { The processing plant: constitutes a } \\
\text { miniaturised replica of a commercial } \\
\text { asbestos processing plant that operates on a } \\
\text { closed-circuit basis }\end{array}$ & $\begin{array}{l}\text { Wind direction relative to inhabitants: only } \\
\text { used in the calculation of the RPI value } \\
\text { when the dominant wind direction fell } \\
\text { within } 270^{\circ} \text { of the direction relative to } \\
\text { where the inhabitants live }\end{array}$ & $\begin{array}{l}\text { Number of inhabitants in the nearest } \\
\text { settlement in direction of waterway }\end{array}$ \\
\hline \multirow{3}{*}{$\begin{array}{l}\text { Percentage short fibre: characterises that } \\
\text { fraction of the total percentage of free fibre } \\
\text { which is short enough to pass through a } \\
-30 \text { mesh sieve }\end{array}$} & $\begin{array}{l}\text { Dominant wind speed: calculated irrespective } \\
\text { of whether the dominant wind direction } \\
\text { was found to occur in summer or winter }\end{array}$ & $\begin{array}{l}\text { Distance of the nearest settlement in } \\
\text { direction of waterway }\end{array}$ \\
\hline & $\begin{array}{l}\text { Distance of inhabitants in the dominant } \\
\text { wind direction }\end{array}$ & $\begin{array}{l}\text { Three types of erosion: evident on areas } \\
\text { where sampling occurred, including: } \\
\text { - Ripple erosion } \\
\text { - Gully erosion } \\
\text { - Slide erosion }\end{array}$ \\
\hline & $\begin{array}{l}\text { Number of inhabitants in the dominant } \\
\text { wind direction }\end{array}$ & $\begin{array}{l}\text { Type of drainage system: using the } \\
\text { following definitions as guidelines }{ }^{\mathrm{a}} \text { : } \\
\text { - Perennial river } \\
\text { - Ephemeral river } \\
\text { - Wetland } \\
\text { - Flood plain } \\
\text { Terrain type: using the following } \\
\text { definitions as guidelines }{ }^{\mathrm{b}} \text { : } \\
\text { - Flood plain } \\
\text { - Steep slope }\left(>18^{\circ}\right) \\
\text { - Mild slope }\left(<18^{\circ}\right) \\
\text { - Plateau }\end{array}$ \\
\hline
\end{tabular}

${ }^{a}$ Provision where none of the definitions was applicable to a specific site was also made. These data was verified by comparison with 1:50,000 maps of the respective areas

b Where none of the above is applicable, a value indicating no influence ("no data") can be used

value depending on the relative estimated exposed surface area of the pollution source. This fractional contribution was determined by the relative size of the exposed surface area that could vary between one and five, divided by five and multiplied by40. In relative terms the largest potential mine pollution source in the database was considered to be a five in size, being the Msauli complex, while a potential pollution source the size of Zukudu was considered to be a one in size. The percentage short fibre present in the total free fibre content contributed the remainder, up to a maximum of $10 \%$, to the potential $50 \%$. Of the qualitative data parameters; the potential for air pollution (composed of six variables), the potential for erosion and other general pollution (composed of nine variables), safety and aesthetics could potentially contribute $25,19.5,5$ and $0.5 \%$, respectively to the calculated RPI value. Actual and normalised values, their units and ascribed weights used during the calculation of the RPIvalue are indicated in Table 2 .

\section{Classification method and results}

Two mine localities previously identified as high-risk localities were selected as case studies to illustrate the calculation of the RPI value (Table 3). The Whitebank 
Table 2 Actual and normalised values, their units and ascribed weights used during the calculation of the rehabilitation prioritisation index (RPI) value

\begin{tabular}{|c|c|c|c|}
\hline Description of factor & Units & Actual and normalised values & Weight \\
\hline \multicolumn{4}{|l|}{ Fibre hazard: } \\
\hline $\begin{array}{l}\text { Total percentage of free } \\
\text { fibre }\end{array}$ & $\%$ & $\begin{array}{l}\text { If }<1.8 \text { then weight }=0 ; \text { if } \geq 1.8 \\
\text { then weight }=\text { scale } / 5^{*} 40\end{array}$ & \\
\hline $\begin{array}{l}\text { Short fibre as a percentage } \\
\text { of free fibre }\end{array}$ & $\%$ & Short fibre & 0.01 \\
\hline \multicolumn{4}{|l|}{ Potential air pollution: } \\
\hline $\begin{array}{l}\text { Distance of nearest } \\
\text { settlement from pollution } \\
\text { source }\end{array}$ & Metre (m) & $\begin{array}{l}0-499-100 \\
500-999-90 \\
1,000-1,999-70 \\
2,000-2,999-50 \\
3,000-3,999-35 \\
4,000-4,999-20 \\
5,000-30,000-5 \\
30,001-900,000-0\end{array}$ & 0.04 \\
\hline Number of inhabitants & Number & $\begin{array}{l}50-0000-100 \\
40-49-80 \\
30-39-65 \\
20-29-50 \\
10-19-35 \\
1-9-20 \\
0-0-0\end{array}$ & 0.03 \\
\hline $\begin{array}{l}\text { Wind direction relative to } \\
\text { inhabitants }\end{array}$ & Number & $\begin{array}{l}100 \% \text { in direction of inhabitants } 100 \\
75 \% \text { in direction of inhabitants } 75 \\
50 \% \text { in direction of inhabitants } 50 \\
25 \% \text { in direction of inhabit } 25 \\
0 \% \text { in direction of inhabitants } 0\end{array}$ & 0.05 \\
\hline $\begin{array}{l}\text { Winter/summer most } \\
\text { dominant wind speed }\end{array}$ & $\mathrm{km} / \mathrm{h}$ & $\begin{array}{l}30-50,000-100 \\
20-29-50 \\
10-19-25 \\
4-9-15 \\
0-3-0\end{array}$ & 0.06 \\
\hline $\begin{array}{l}\text { Distance of inhabitants } \\
\text { (winter/summer most } \\
\text { dominant wind direction) }\end{array}$ & $\mathrm{km}$ & $\begin{array}{l}0-99-100 \\
100-199-90 \\
200-299-80 \\
300-399-70 \\
400-499-60 \\
500-999-50 \\
1,00-2,999-40 \\
3,000-4,999-35 \\
5,000-9,999-30 \\
10,000-24,999-25 \\
25,000-49,999-10 \\
50,000-500,000-0\end{array}$ & 0.02 \\
\hline $\begin{array}{l}\text { Number of inhabitants } \\
\text { (winter/summer most } \\
\text { dominant wind direction) }\end{array}$ & Number & $\begin{array}{l}50-100,000-100 \\
40-49-80 \\
30-39-65 \\
20-29-50 \\
10-19-35 \\
1-9-20 \\
0-0-0\end{array}$ & 0.05 \\
\hline
\end{tabular}


Table 2 continued

\begin{tabular}{|c|c|c|c|}
\hline Description of factor & Units & Actual and normalised values & Weight \\
\hline Annual rainfall & $\begin{array}{l}\text { Millimetres per annum } \\
\text { (mm/pa) }\end{array}$ & $\begin{array}{l}900-9,999-100 \\
700-899-90 \\
500-699-75 \\
300-499-50 \\
200-99-25 \\
1-199-10 \\
0-0-0\end{array}$ & 0.03 \\
\hline Located in waterway & Yes/no & $\begin{array}{l}\text { Yes } 100 \\
\text { No } 0\end{array}$ & 0.035 \\
\hline $\begin{array}{l}\text { Number of inhabitants in } \\
\text { nearest settlement in the } \\
\text { direction of waterway }\end{array}$ & Number & $\begin{array}{l}50-30,000-100 \\
40-49-80 \\
30-39-65 \\
20-29-50 \\
10-19-35 \\
1-9-20 \\
0-0-0\end{array}$ & 0.025 \\
\hline $\begin{array}{l}\text { Distance of nearest } \\
\text { settlement in the } \\
\text { direction of waterway }\end{array}$ & $\mathrm{m}$ & $\begin{array}{l}0-499-100 \\
500-999-90 \\
1,000-1,999-80 \\
2,000-2,999-50 \\
3,000-4,999-20 \\
5,000-9,999-10 \\
10,000-99,999-5 \\
100,000-9,999,999-0\end{array}$ & 0.02 \\
\hline Erosion: ripple & $\begin{array}{l}\text { Yes/no } \\
\text { Number }\end{array}$ & $\begin{array}{l}100-30,000-100 \\
50-99-90 \\
30-49-50 \\
10-29-30 \\
1-9-10 \\
0-0-0\end{array}$ & 0.01 \\
\hline Erosion: gully & $\begin{array}{l}\text { Yes/no } \\
\text { Number }\end{array}$ & $\begin{array}{l}10-1,000-100 \\
6-9-90 \\
3-5-75 \\
2-2-50 \\
1-1-25 \\
0-0-0\end{array}$ & 0.03 \\
\hline Erosion: slip & Yes/no & $\begin{array}{l}4-30,000-100 \\
3-3-75 \\
2-2-50 \\
1-1-25\end{array}$ & 0.03 \\
\hline Type of drainage system & Number & $\begin{array}{l}\text { Perennial river-100 } \\
\text { Perennial small river-95 } \\
\text { Ephemeral river-80 } \\
\text { Perennial tributary/rivulet-60 } \\
\text { Ephemeral tributary/rivulet-50 } \\
\text { Ephemeral stream-40 } \\
\text { Flood plain-30 } \\
\text { Wetland-15 } \\
\text { Hollow-10 } \\
\text { None-0 }\end{array}$ & 0.005 \\
\hline
\end{tabular}


Table 2 continued

\begin{tabular}{|c|c|c|c|}
\hline Description of factor & Units & Actual and normalised values & Weight \\
\hline \multirow[t]{5}{*}{ Terrain type } & \multirow[t]{10}{*}{ Description } & Flood plain—100 & 0.01 \\
\hline & & Slope $>18$ (steep) -75 & \\
\hline & & Slope $<18-25$ & \\
\hline & & Plateau-10 & \\
\hline & & No data -0 & \\
\hline \multirow[t]{5}{*}{ Safety } & & $10-30,000-100$ & 0.05 \\
\hline & & $5-9-75$ & \\
\hline & & $2-4-50$ & \\
\hline & & $1-1-25$ & \\
\hline & & $0-0-0$ & \\
\hline \multirow[t]{2}{*}{ Aesthetics } & & Yes 100 & 0.005 \\
\hline & & No 0 & \\
\hline
\end{tabular}

Table 3 Case studies of two high-risk mines, illustrating the calculation of the RPI value

\begin{tabular}{|c|c|c|}
\hline Description of factor & Whitebank & Senekal \\
\hline RPI & 69.33 & 71.33 \\
\hline \multicolumn{3}{|l|}{ Fibre hazard } \\
\hline Total $\%$ free fibre & 8.46 & 2.17 \\
\hline Short fibre as $\%$ of free fibre & 86.93 & 96.33 \\
\hline \multicolumn{3}{|l|}{ Potential air pollution } \\
\hline Distance of the nearest settlement from pollution source $(\mathrm{m})$ & $500(90)$ & $10(100)$ \\
\hline Number of inhabitants & $60(100)$ & $100(100)$ \\
\hline Wind direction relative to inhabitants & $\begin{array}{l}100 \% \text { in direction of inhabitants } \\
\text { (100) }\end{array}$ & $\begin{array}{l}100 \% \text { in direction of inhabitants } \\
(100)\end{array}$ \\
\hline Winter/summer most dominant wind speed $(\mathrm{km} / \mathrm{h})$ & $3.77(15)$ & $0(0)$ \\
\hline $\begin{array}{l}\text { Distance of inhabitants (winter/summer most dominant wind } \\
\text { direction) }\end{array}$ & $500(50)$ & $10(100)$ \\
\hline $\begin{array}{l}\text { Number of inhabitants (winter/summer most dominant wind } \\
\text { direction) }\end{array}$ & $60(100)$ & $100(100)$ \\
\hline \multicolumn{3}{|l|}{ Potential erosion and general pollution } \\
\hline Annual rainfall (mm) & $410(50)$ & $700(90)$ \\
\hline Located in waterway & Yes $(100)$ & Yes $(100)$ \\
\hline $\begin{array}{l}\text { Number of inhabitants in nearest settlement in direction of } \\
\text { waterway }\end{array}$ & $30(65)$ & $200(100)$ \\
\hline Distance of nearest settlement in direction of waterway & $5,000(10)$ & $100(100)$ \\
\hline Erosion: ripple & Yes $20(30)$ & Yes $20(30)$ \\
\hline Erosion: gully & Yes $6(90)$ & Yes $10(100)$ \\
\hline Erosion: slip & No $(0)$ & No $(0)$ \\
\hline Type of drainage system & Ephemeral stream (40) & Ephemeral stream (40) \\
\hline Terrain type & Slope $>18(75)$ & Slope $<18(25)$ \\
\hline Safety & None, no highwalls $(0)$ & Yes 5 highwalls (100) \\
\hline Aesthetics & Yes (100) & Yes $(100)$ \\
\hline
\end{tabular}

Normalised values are indicated in brackets

mine is an amphibole asbestos mine, while the Senekal mine is a chrysotile asbestos mine. The calculated RPI value for both these mines indicated a high priority for rehabilitation.

\section{Discussion}

The development of the asbestos RPI means that for the first time there is a scientifically based method to determine 
the need for rehabilitation of asbestos pollution by quantifying the risk associated with a specific pollution site. It is important to realise that the success of rehabilitation necessarily depends on the sustainability of the rehabilitative measures applied. This is also applicable to the RPI and explains the importance of frequently revising the information used in the database to ensure relevant and accurate risk assessments.

The database contains information for 113 mines and 144 mine dumps from four provinces in South Africa (Gauteng, Mpumalanga, Northern Cape and Northern Province). Each mine was assessed according to a number of defined parameters and weighted factors as indicated in Tables 1 and 2. The cost of rehabilitation for each mine, as well as the total cost of rehabilitation of all the mines in a specific province can also be determined from the database.

Though the establishment of RPI is a fruitful departure from current, more subjective methods, it is dependant on the quality of the data in the database. In this regard there are some areas of concern in the current databases. The areas of concern pertain mainly to the qualitative data. For example, obtaining the correct rainfall figures and wind direction/speed relevant to a specific mine pollution source is not as simple as it seems, as the first and second order weather stations that gathered the relevant information were sometimes situated kilometres away from the specific mine pollution source in question and assumptions had to be made as described in the definitions. The qualitative data used for calculation of the RPI, included variables such as demographic, geographic, safety and aesthetical considerations that were very difficult to quantify exactly and will always be subjective depending on the experience of the individual who collected the information. Furthermore, it should be realised that some of the qualitative data collected, for example the number of inhabitants in the prevailing wind direction, are not static and will likely change with time necessitating constant updates.

\section{Concluding remarks}

The use of the asbestos RPI has been implemented by the South African Department of Minerals and Energy as part of the governments integrated and co-operative approach towards the rehabilitation of the asbestos legacies of the past. In accordance with this index, 145 derelict and ownerless asbestos mines/dumps have been identified, of which only 84 still need to be rehabilitated.

Acknowledgments The authors would like to acknowledge the input and vision of the personnel from Eco Rehab, in particular that of Dr J Booysen for his management of this project and Ms R Nel for her effort in compiling the database.

Open Access This article is distributed under the terms of the Creative Commons Attribution Noncommercial License which permits any noncommercial use, distribution, and reproduction in any medium, provided the original author(s) and source are credited.

\section{References}

Anon (2001) Asbestos-related disease in South Africa: opportunities and challenges remaining since the 1998 parliamentary asbestos summit. A report presented to The Parliamentary Portfolio Committee on Environmental Affairs and Tourism. 12 October 2001 http://www.brown.edu/Departments/African_American_ Studies/Asbestos

Anon (2004) What is the logic being applied by anti-asbestos activists? The Asbestos Institute, Montreal, Canada. http://www. asbestos-institute.ca

Harris LV, Kahwa IA (2003) Asbestos: old foe in 21st century developing countries. Sci Total Environ 307:1-9

McDonald JC, McDonald AD (1997) Chrysotile, asbestos and carcinogenity. Ann Occup Hyg 41:669-705

Natural Resources Canada (2000) Chrysotile asbestos fact sheet. http://www.nrcan.gc.ca/mms/pdf/chry_e.pdf. Accessed June 2004

NICNAS (1999) National Industrial Chemicals Notification and Assessment Scheme. Chrysotile asbestos priority existing chemical no. 9-full public report. http://www.nicnas.gov.au/ publications/CAR/PEC/PEC9/PEC9index.htm. Accessed June 2004

Tossavainen A, Kotilainen M, Takahashi K, Pan G, Vanhala E (2001) Amphibole fibres in chinese chrysotile asbestos. Ann Occup Hyg 45:145-152 